\title{
Antimicrobial Activity of Paepalanthus planifolius and its Major Components against Selected Human Pathogens
}

\author{
Marcelo R. de Amorim, ${ }^{a}$ Felipe Hilário, ${ }^{b}$ Paulo T. Sano, ${ }^{c}$ Tais M. Bauab ${ }^{b}$ and \\ Lourdes C. dos Santos*,a \\ ${ }^{a}$ Departamento de Química Orgânica, Instituto de Química and \\ ${ }^{b}$ Departamento de Ciências Biológicas, Escola de Ciências Farmacêuticas, \\ Universidade Estadual Paulista (UNESP), 14800-900 Araraquara-SP, Brazil
}

cDepartamento de Botânica, Instituto de Biociências, Universidade de São Paulo (USP), 05508-090 São Paulo-SP, Brazil

\begin{abstract}
The chemical investigation of ethyl acetate extract from Paepalanthus planifolius capitula resulted in the identification of $1 H$-naphtho[2,3-c]pyran-1-one,9-[(6-O- $\beta$-D-glucopyranosyl$\beta$-D-glucopyranosyl)oxy]-3,4-dihydro-10-hydroxy-7-methoxy-3-methyl, semi-vioxanthin 9-O- $\beta$-D-glucopyranoside, toralactone-9-O- $\beta$-D-glucopyranoside, paepalantine9-O- $\beta$-D-glucopyranoside, semi-vioxanthin, $1 H$-naphtho[2,3-c]pyran-1-one,3,4-dihydro9,10-dihydroxy-5,7-dimethoxy-3-methyl, vioxanthin and paepalantine dimer, and also the isolation and identification of a new naphthopyranone dimer named planifoliusin A. The chemical structures of two compounds were elucidated by performing spectroscopic 1D and 2D nuclear magnetic resonance (NMR) experiments and spectrometric HRMS (high-resolution mass spectrometry) analysis. Other six naphthopyranone dimers were proposed by MS fragmentation patterns. The minimum inhibitory concentration (MIC) values for vioxanthin $(7.8 \mu \mathrm{g} \mathrm{mL}-1)$, planifoliusin A $\left(15.6 \mu \mathrm{g} \mathrm{mL}^{-1}\right)$ and the ethyl acetate extract $\left(31.2 \mu \mathrm{g} \mathrm{mL} \mathrm{m}^{-1}\right)$ showed antimicrobial activity against Staphylococcus aureus (ATCC 25923).
\end{abstract}

Keywords: Paepalanthus planifolius, naphthopyranone, antimicrobial activity

\section{Introduction}

Staphylococcus aureus is a leading cause of bacterial infections in hospitals and communities worldwide, and is one of the most important agents responsible for healthcare-associated infections, it has been estimated that around $20-30 \%$ of the human population are carriers of $S$. aureus. The increased occurrence of methicillin resistant S. aureus (MRSA) strains has created genuine clinical and therapeutical problems. ${ }^{1}$

Considering that the antimicrobial resistances have been raised as a concern and the necessity to search for new antimicrobials agents as potential candidates for the treatment of several bacteria and fungi species, it is even more relevant to discover antimicrobial drugs. ${ }^{2}$

Eriocaulaceae are ornamental plants popularly known as "evergreens" and comprise about 1200 species in 10 genera. $^{3}$ Among these genus, Paepalanthus has approximately 357 species which $95 \%$ are endemic species restricted to Espinhaço Range in Brazil. ${ }^{4,5}$ Although Eriocaulaceae are used in the manufacture of ornamental products, literature reports studies with Eriocaulaceae species that have promising antimicrobial activity. ${ }^{6,7}$ Other studies have previously demonstrated the importance of extract and isolated substances in the Eriocaulaceae family, mainly because they present a great biological potential, such as the already identified antioxidant activities, ${ }^{8,9}$ cytotoxic, ${ }^{10,11}$ antiulcerogenic, ${ }^{12}$ antibacterial and vulvovaginal candidiasis treatment. ${ }^{13,14}$

Thus, in search of new biological compounds we described the antimicrobial activity of ethyl acetate (EtOAc) extract of capitula from Paepalanthus planifolius and its phytochemical characterization. Furthermore, the antimicrobial activities of isolated compounds were evaluated.

*e-mail: loursant@gmail.com 


\section{Results and Discussion}

Antimicrobial activities and identification of naphthopyranones in the extract

The minimum inhibitory concentration (MIC), minimum bactericidal concentration (MBC) and minimum fungicidal concentration (MFC) for the antimicrobial activity of the capitula EtOAc extract were evaluated against four human pathogenic microorganisms: Escherichia coli (ATCC 25922), Salmonella setubal (ATCC 19196), Staphylococcus aureus (ATCC 25923) and Candida albicans (ATCC 10231). Antimicrobial activity is considered good if the extract MIC values displayed lower than $100 \mu \mathrm{g} \mathrm{mL}^{-1}$; moderate from 100 to $500 \mu \mathrm{g} \mathrm{mL}^{-1}$; weak from 500 to $1000 \mu \mathrm{g} \mathrm{mL} \mathrm{m}^{-1}$; and over $1000 \mu \mathrm{g} \mathrm{mL}^{-1}$ the extract is considered inactive. ${ }^{15}$ Then the EtOAc extract showed a moderate activity against the Gram-negative bacteria tested, which displayed MIC values of $500 \mu \mathrm{g} \mathrm{mL}^{-1}$. For the Gram-positive bacteria, it was considered a good activity (MIC value of $31.2 \mu \mathrm{g} \mathrm{mL}^{-1}$ ), while for the yeast fluconazole-resistant $C$. albicans, it was shown a low activity (Table 1). Once that the extract showed promised activity against $S$. aureus, we performed its chemical study.

A preliminary analysis of the EtOAc extract of $P$. planifolius capitula by LC-ESI-TOF-HRMS (liquid chromatography-electrospray ionization-time-of-flighthigh resolution mass spectrometry) and LC-ESI-IT-MS/MS (liquid chromatography-electrospray ionization-ion trap-tandem mass spectrometry) revealed the presence of naphthopyranone derivatives, $1 H$-naphtho[2,3-c]pyran1-one,9-[(6-O- $\beta$-D-glucopyranosyl- $\beta$-D-glucopyranosyl) oxy]-3,4-dihydro-10-hydroxy-7-methoxy-3-methyl (1), semi-vioxanthin 9-O- $\beta$-D-glucopyranoside (2), toralactone-9- $O$ - $\beta$-D-glucopyranoside $(3)$, paepalantine9-O- $\beta$-D-glucopyranoside (4), semi-vioxanthin (5), $1 H$-naph tho [2,3-c]pyran-1-one, 3,4-dihydro- 9,10-dihydroxy-5,7-dimethoxy-3-methyl (6), vioxanthin (7) and paepalantine dimer (8) (Figure 1). Other peaks (9-15) also showed absorption spectra in the UV of naphthopyranones, but were not found in the literature (Table 2, Figure 2). Then, the extract was carried out by the fractionation of gel permeation chromatography (Sephadex LH-20 column) and subjected to a purification using semipreparative HPLCDAD (high-performance liquid chromatography-diode array detector), resulting in the isolation of a new compound named planifoliusin A (9) and the known vioxanthin (7) (Figure 1). The analogues planifoliusin B (10), planifoliusin C (11), planifoliusin D (12), planifoliusin E (13), planifoliusin F (14) and planifoliusin $\mathrm{G}$ (15) were proposed comparing the MS fragmentation patterns with planifoliusin A (9) and vioxanthin (7) and its UV spectra (see Supplementary Information).

Naphthopyranones exhibit a wide biological activity, including antimicrobial, anti-inflammatory, mutagenic, cytotoxic properties, among others. ${ }^{21}$ Thus, it is possible to relate that the good antimicrobial activity presented by the EtOAc extract of $P$. planifolius comes from this major naphthopyranones identified in the extract.

\section{Elucidation of planifoliusin A (9)}

Planifoliusin A (9) was isolated as an amorphous yellow powder and the LC-HRMS analysis exhibited an ion at $m / z .575 .1547[\mathrm{M}+\mathrm{H}]^{+}$(calcd. 575.1548), suggesting the molecular formula $\mathrm{C}_{31} \mathrm{H}_{26} \mathrm{O}_{11}$.

Compound 9 was elucidated by nuclear magnetic resonance (NMR) spectra, including ${ }^{1} \mathrm{H},{ }^{13} \mathrm{C}$, HSQC (heteronuclear single quantum correlation), HMBC (heteronuclear multiple bond correlation) and ${ }^{1} \mathrm{H}-{ }^{1} \mathrm{H}$ COSY (correlation spectroscopy), and showed some similarities when compared to paepalantine dimer and vioxanthin isolated from the Paepalanthus species. ${ }^{18,20}$ The ${ }^{1} \mathrm{H}$ NMR spectrum displayed four signals of aromatic hydrogens at

Table 1. Antimicrobial activity of P. planifolius extract and compounds $\mathbf{7}$ and 9

\begin{tabular}{|c|c|c|c|c|}
\hline \multirow{3}{*}{ Sample } & \multicolumn{3}{|c|}{$\mathrm{MIC}(\mathrm{MBC}) /\left(\mu \mathrm{g} \mathrm{mL}^{-1}\right)$} & \multirow{3}{*}{$\begin{array}{c}\mathrm{MIC}(\mathrm{MFC}) /\left(\mu \mathrm{g} \mathrm{mL}^{-1}\right) \\
\text { Yeast } \\
\text { C. albicans }\end{array}$} \\
\hline & \multicolumn{2}{|c|}{ Gram-negative } & \multirow{2}{*}{$\begin{array}{c}\text { Gram-positive } \\
\text { S. aureus }\end{array}$} & \\
\hline & E. coli & S. setubal & & \\
\hline Extract & $500(1000)$ & $500(1000)$ & $31.2(500)$ & a \\
\hline 7 & $500(1000)$ & $1000(1000)$ & $7.8(250)$ & a \\
\hline 9 & $1000(1000)$ & $500(1000)$ & $15.6(62.5)$ & a \\
\hline Ampicillin & 6.25 & 12.5 & 0.15 & a \\
\hline Amphoterecin B & NA & NA & NA & 10.0 \\
\hline Fluconazole & NA & NA & NA & ND \\
\hline
\end{tabular}

${ }^{\mathrm{a}} \mathrm{MIC}>1000.0 \mu \mathrm{g} \mathrm{mL}{ }^{-1}$. NA: not applicable; ND: not detected. 
<smiles>[R]c1c2c(c(O)c3c([R])cc(OC)cc13)C(=O)O[C@H](C)C2</smiles>

$\mathrm{R}_{1} \quad \mathrm{R}_{2}$

$1 \mathrm{H} \quad \mathrm{O}-\mathrm{glu}-(6,1)-\mathrm{glu}$

$2 \mathrm{H} \quad \mathrm{O}-\mathrm{glu}$

5 H $\mathrm{OH}$

$6 \mathrm{OCH}_{3} \mathrm{OH}$<smiles>[R]c1c2cc(OC)cc(OC3OC(CO)C(O)C(O)C3O)c2c(O)c2c(=O)oc(C)cc12</smiles>

$R_{1}$

$3 \mathrm{H}$

$4 \mathrm{OCH}_{3}$<smiles></smiles><smiles></smiles><smiles></smiles>

10

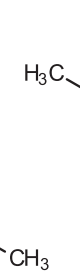<smiles>COc1cc2c(O)c3c(c(O)c2c(O)c1-c1c(O)cc2c(C)c4cc(F)oc(=O)c4c(O)c2c1O)C(=O)OC(C)C3</smiles>

12

13<smiles>CCOCCO</smiles>

14<smiles>COc1cc2c(O)c3ccoc(=O)c3c(O)c2c(O)c1-c1c(OC)cc2cc(C)oc(=O)c2c1O</smiles>

15

Figure 1. Naphthopyranones identified of capitula from Paepalanthus planifolius.

$\delta_{\mathrm{H}} 6.72(\mathrm{~s}, 1 \mathrm{H}, \mathrm{H}-6), 6.97$ (s, 1H, H-5), 6.57 (s, 1H, H-4') and $7.06\left(\mathrm{~s}, 1 \mathrm{H}, \mathrm{H}-6\right.$ '). Other signals at $\delta_{\mathrm{H}} 3.03(\mathrm{~m}, 2 \mathrm{H}$, $\left.\mathrm{H}_{2}-4\right)$ and $4.78(\mathrm{~m}, 1 \mathrm{H}, \mathrm{H}-3)$ were assigned to the methylene and methine groups, respectively (Table 3 ). It was observed the signals of three methoxyl groups at $\delta_{\mathrm{H}} 3.93(\mathrm{~s}, 3 \mathrm{H}$, H-13'), 3.91 (s, 3H, H-12') and 3.86 (s, 3H, H-12) and two methyl groups at $\delta_{\mathrm{H}} 2.32\left(\mathrm{~s}, 3 \mathrm{H}, \mathrm{H}-11^{\prime}\right)$ and $1.56(\mathrm{~d}$,
$3 \mathrm{H}, J 6.0 \mathrm{~Hz}, \mathrm{H}-11)$. The signals at $\delta_{\mathrm{H}} 13.81$ (s, $\left.1 \mathrm{H}, \mathrm{H}-10\right)$, 13.44 (s, 1H, H-10'), 9.74 (s, 1H, H-9) and 9.75 (s, 1H, H-9') were attributed to hydroxyl groups.

The ${ }^{13} \mathrm{C}$ NMR spectrum of 9 presented 31 signals of which two peaks were assignable to the carbonyls of the lactone ring at $\delta_{\mathrm{C}} 171.7(\mathrm{C}-1)$ and $168.4\left(\mathrm{C}-1^{\prime}\right)$ (Table 3) and 16 signals correlated well with those of paepalantine. ${ }^{19}$ 
Table 2. Naphthopyranones identified by LC-HRMS and LC-MS/MS of EtOAc extract from P. planifolius capitula

\begin{tabular}{|c|c|c|c|c|c|c|c|c|c|}
\hline Substance & Peak & $\mathrm{t}_{\mathrm{R}} / \min$ & Ion type & $\begin{array}{l}\text { Measured } \\
\text { mass }\end{array}$ & $\begin{array}{l}\text { Calculated } \\
\text { mass }\end{array}$ & $\begin{array}{c}\text { Mass error / } \\
\text { ppm }\end{array}$ & $\begin{array}{l}\text { MS/MS ion } \\
\text { fragments }\end{array}$ & $\begin{array}{l}\text { UV spectra } \\
\lambda_{\max } / \mathrm{nm}\end{array}$ & Reference \\
\hline $\begin{array}{l}1 H \text {-Naphtho[2,3-c]pyran- } \\
\text { 1-one,9-[(6-O- } \beta \text {-D- } \\
\text { glucopyranosyl- } \beta \text {-D- } \\
\text { glucopyranosyl)oxy]- } \\
\text { 3,4-dihydro-10-hydroxy- } \\
\text { 7-methoxy-3-methyl }\end{array}$ & 1 & 4.1 & {$[\mathrm{M}+\mathrm{Na}]^{+}$} & 621.1786 & 621.1790 & 0.6 & $603,347,297$ & $263,310,360$ & $\begin{array}{l}\text { Vilegas } \\
\text { et al. }^{16}\end{array}$ \\
\hline $\begin{array}{l}\text { Semi-vioxanthin 9-O- } \beta \text {-D- } \\
\text { glucopyranoside }\end{array}$ & 2 & 4.9 & {$[\mathrm{M}+\mathrm{Na}]^{+}$} & 459.1274 & 459.1262 & -2.8 & 441,297 & $261,295,360$ & $\begin{array}{l}\text { Vilegas } \\
\text { et al. }{ }^{16}\end{array}$ \\
\hline $\begin{array}{l}\text { Toralactone-9- } O-\beta-\mathrm{D}- \\
\text { glucopyranoside }\end{array}$ & 3 & 6.0 & {$[\mathrm{M}+\mathrm{Na}]^{+}$} & 457.1109 & 457.1105 & -0.8 & 439,295 & $279,278,378$ & $\begin{array}{l}\text { Fang } \\
\text { et al. }^{13}\end{array}$ \\
\hline $\begin{array}{l}\text { Paepalantine-9- } O-\beta-\mathrm{D}- \\
\text { glucopyranoside }\end{array}$ & 4 & 6.4 & {$[\mathrm{M}+\mathrm{Na}]^{+}$} & 487.1217 & 487.1211 & -1.3 & 469,325 & $272,282,378$ & $\begin{array}{l}\text { Vilegas } \\
\text { et al. }{ }^{17}\end{array}$ \\
\hline Semi-vioxanthin & 5 & 15.3 & {$[\mathrm{M}+\mathrm{H}]^{+}$} & 275.0919 & 275.0914 & -1.8 & $257,247,243$ & 261,370 & $\begin{array}{c}\text { Alvorado } \\
\text { et al. } .^{18}\end{array}$ \\
\hline $\begin{array}{l}1 H \text {-Naphtho[2,3-c] } \\
\text { pyran-1-one,3,4-dihydro- } \\
\text { 9,10-dihydroxy- } \\
\text { 5,7-dimethoxy-3-methyl }\end{array}$ & 6 & 16.5 & {$[\mathrm{M}+\mathrm{H}]^{+}$} & 305.1029 & 305.1020 & -3.0 & $287,277,272$ & 263,373 & $\begin{array}{l}\text { Vilegas } \\
\text { et al. }{ }^{19}\end{array}$ \\
\hline Vioxanthin & 7 & 20.3 & {$[\mathrm{M}+\mathrm{H}]^{+}$} & 547.1597 & 547.1599 & 0.3 & 529,274 & 268,377 & $\begin{array}{l}\text { Alvorado } \\
\text { et al. }{ }^{18}\end{array}$ \\
\hline Planifoliusin B & 10 & 21.6 & {$[\mathrm{M}+\mathrm{H}]^{+}$} & 577.1696 & 577.1704 & 1.4 & $\begin{array}{c}559,303,304, \\
274\end{array}$ & 268,378 & - \\
\hline Planifoliusin C & 11 & 23.0 & {$[\mathrm{M}+\mathrm{H}]^{+}$} & 607.1797 & 607.1810 & 2.2 & $\begin{array}{c}589,303,304, \\
275\end{array}$ & 269,378 & - \\
\hline Planifoliusin D & 12 & 25.8 & {$[\mathrm{M}+\mathrm{H}]^{+}$} & 545.1433 & 545.1442 & 1.7 & $\begin{array}{c}527,274,272, \\
256\end{array}$ & $\begin{array}{l}272,282 \\
294 \text { sh, } 380\end{array}$ & - \\
\hline Planifoliusin A & 9 & 27.5 & {$[\mathrm{M}+\mathrm{H}]^{+}$} & 575.1547 & 575.1548 & 0.2 & $557,301,273$ & $\begin{array}{l}274,285 \\
296 \mathrm{sh}, 380\end{array}$ & - \\
\hline Planifoliusin E & 13 & 29.0 & {$[\mathrm{M}+\mathrm{H}]^{+}$} & 605.1643 & 605.1654 & 1.8 & $587,304,301$ & $\begin{array}{l}274,284 \\
296 \text { sh, } 380\end{array}$ & - \\
\hline Planifoliusin F & 14 & 31.7 & {$[\mathrm{M}+\mathrm{H}]^{+}$} & 543.1281 & 543.1286 & 0.8 & 525,272 & $\begin{array}{l}274 \text { sh, } 286 \\
296,389\end{array}$ & - \\
\hline Planifoliusin G & 15 & 33.5 & {$[\mathrm{M}+\mathrm{H}]^{+}$} & 573.1380 & 573.1391 & 2.0 & $555,301,302$ & $\begin{array}{l}274 \text { sh, } 288 \\
296,396\end{array}$ & - \\
\hline Paepalantine dimer & 8 & 35.4 & {$[\mathrm{M}+\mathrm{H}]^{+}$} & 603.1498 & 603.1497 & -0.2 & $-^{\mathrm{a}}$ & $\begin{array}{c}274 \text { sh, } 288 \\
296,399\end{array}$ & $\begin{array}{l}\text { Coelho } \\
\text { et al. }{ }^{20}\end{array}$ \\
\hline
\end{tabular}

aauto-MS/MS mode acquisition did not acquire the fragmentations. $t_{\mathrm{R}}$ : retention time.

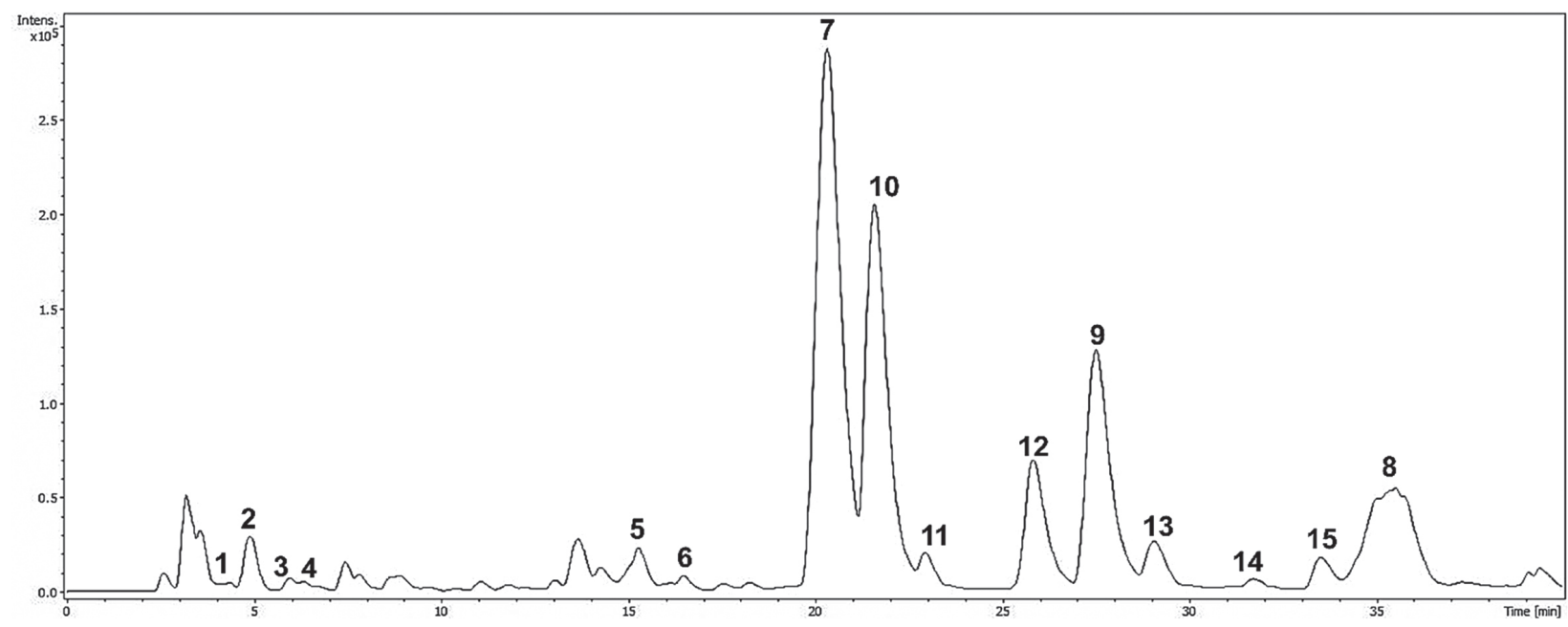

Figure 2. Chromatogram of naphthopyranones of EtOAc extract from P. planifolius by LC-ESI-TOF-MS. 
Table 3. ${ }^{1} \mathrm{H}(600 \mathrm{MHz})$ and ${ }^{13} \mathrm{C}(150 \mathrm{MHz})$ spectroscopic data of planifoliusin $\mathrm{A}(9)$ in $\mathrm{CDCl}_{3}[\delta$ in ppm, multiplicity $(J$ in $\mathrm{Hz})]$

\begin{tabular}{|c|c|c|c|c|c|}
\hline Position & ${ }^{1} \mathrm{H}$ & ${ }^{13} \mathrm{C}$ & Position & ${ }^{1} \mathrm{H}$ & ${ }^{13} \mathrm{C}$ \\
\hline 1 & - & 171.7 & $1^{\prime}$ & - & 168.4 \\
\hline 3 & $4.78 \mathrm{~m}$ & 76.7 & $3^{\prime}$ & - & 152.4 \\
\hline 4 & $3.03 \mathrm{~m}$ & 34.9 & $4^{\prime}$ & $6.57 \mathrm{~s}$ & 99.5 \\
\hline $4 a$ & - & 133.1 & $4 a^{\prime}$ & - & 122.3 \\
\hline 5 & $6.97 \mathrm{~s}$ & 116.3 & 5 & - & 140.6 \\
\hline $5 a$ & - & 140.2 & $5 a^{\prime}$ & - & 135.6 \\
\hline 6 & $6.72 \mathrm{~s}$ & 98.3 & 6 ' & $7.06 \mathrm{~s}$ & 92.4 \\
\hline 7 & - & 161.6 & $7^{\prime}$ & - & 162.1 \\
\hline 8 & - & 108.1 & $8^{\prime}$ & - & 108.6 \\
\hline $9(\mathrm{OH})$ & $9.74 \mathrm{~s}$ & 155.5 & $9^{\prime}(\mathrm{OH})$ & $9.75 \mathrm{~s}$ & 155.9 \\
\hline $9 a$ & - & 108.5 & $9 a^{\prime}$ & - & 108.9 \\
\hline $10(\mathrm{OH})$ & $13.81 \mathrm{~s}$ & 163.0 & $10^{\prime}(\mathrm{OH})$ & $13.44 \mathrm{~s}$ & 158.9 \\
\hline $10 \mathrm{a}$ & - & 99.5 & $10 a^{\prime}$ & - & 96.9 \\
\hline $11\left(\mathrm{CH}_{3}\right)$ & $1.56 \mathrm{~d}(6.0)$ & 20.9 & $11^{\prime}\left(\mathrm{CH}_{3}\right)$ & $2.32 \mathrm{~s}$ & 19.8 \\
\hline \multirow[t]{2}{*}{$12\left(\mathrm{OCH}_{3}\right)$} & $3.86 \mathrm{~s}$ & 56.1 & $12^{\prime}\left(\mathrm{OCH}_{3}\right)$ & $3.91 \mathrm{~s}$ & 56.2 \\
\hline & & & $13^{\prime}\left(\mathrm{OCH}_{3}\right)$ & $3.93 \mathrm{~s}$ & 62.0 \\
\hline
\end{tabular}

$\delta$ : chemical shift; $J$ : coupling constant.

Comparing and contrasting the above information with the data derived from the analysis of the 2D NMR spectra, it was possible to conclude that $\mathbf{9}$ is a naphthopyranone dimeric with a monomeric lactone, similar to paepalantine and the other monomer similar to semi-vioxanthin. ${ }^{18,19}$ The ${ }^{1} \mathrm{H}-{ }^{1} \mathrm{H}$ COSY correlations indicated the sequence H-4 $\leftrightarrow \mathrm{H}-3 \leftrightarrow \mathrm{H}-11$ confirming the presence of semivioxanthin derivatives. ${ }^{19}$ In the HMBC spectrum, diagnostic long range correlations were observed for the unit derived from the semi-vioxanthin between $\mathrm{H}-5$ with the carbons $\mathrm{C}-4, \mathrm{C}-4 \mathrm{a}$ and $\mathrm{C}-5 \mathrm{a}$. The unit of the paepalantine derivative was evident by the correlation of the H-4' with C-4a', C-3' and $\mathrm{C}-5$ '. Additional evidence was given in the HMBC spectrum of which correlations to ${ }^{2} J$ and ${ }^{3} J$ of the $\mathrm{OH}-9$ $\left(\delta_{\mathrm{H}} 9.74\right)$ with $\mathrm{C}-9 \mathrm{a}\left(\delta_{\mathrm{C}} 108.5\right)$ and $\mathrm{OH}-10\left(\delta_{\mathrm{H}} 13.81\right)$ with $\mathrm{C}-10 \mathrm{a}\left(\delta_{\mathrm{C}} 99.5\right)$ were observed, positioning these hydroxyls in the semi-vioxanthin monomer. The hydroxyls belonging to the paepalantine unit were also observed by the correlations in the HMBC spectrum of the hydrogen signal of the hydroxyl $\mathrm{OH}-9$ ' $\left(\delta_{\mathrm{H}} 9.75\right)$ with $\mathrm{C}-8$ ' $\left(\delta_{\mathrm{C}} 108.6\right)$ and the $\mathrm{OH}-10$ ' $\left(\delta_{\mathrm{H}} 13.44\right)$ with $\mathrm{C}-10 \mathrm{a}$ ' $\left(\delta_{\mathrm{C}} 96.9\right)$. Therefore, what remains is to connect the monomer of the paepalantine and of the semi-vioxanthin. The non-observance of $\mathrm{H}-6 / \mathrm{H}-8$ meta coupling and $\mathrm{H}-\mathrm{6}^{\prime} / \mathrm{H}-8^{\prime}$ ' coupling combined with the chemical shift of C-8 $\left(\delta_{\mathrm{C}} 108.1\right)$ and $\mathrm{C}-8^{\prime}\left(\delta_{\mathrm{C}} 108.6\right)$ made it possible to establish that the linkage between two monomeric units is between $\mathrm{C}-8 / \mathrm{C}-8$ '. Thus, the compound 9 was proposed to be made up by two different monomeric portions, semi-vioxanthin and paepalantine, linked through a C-8/C-8' bond (Figure 3).

The CD (circular dichroism) spectrum of planifoliusin A (9) showed negative Cotton effect at $293 \mathrm{~nm}$ that corresponds to $\mathrm{n} \rightarrow \pi^{*}$ transition (CO lactone) (Figure 4). Comparison of this negative Cotton effect with $(R)$-semivioxanthin revealed the absolute configuration at C-3 of planifoliusin A to be $R^{22}$

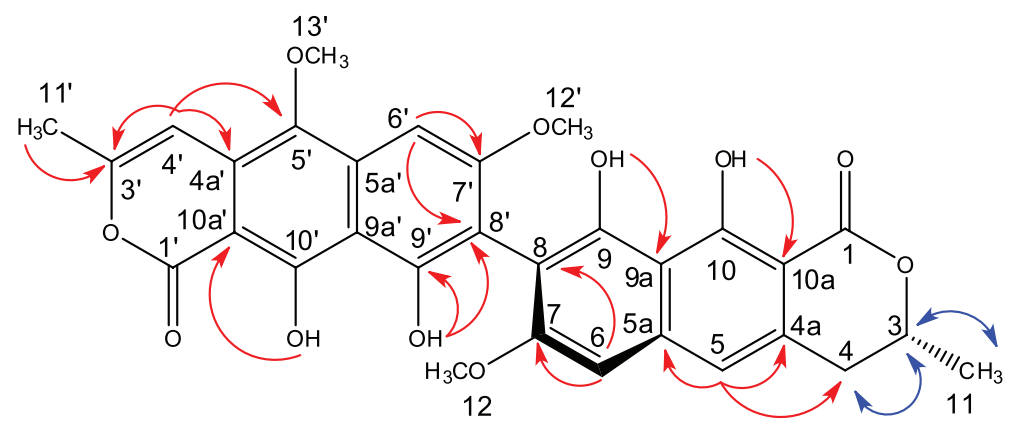

Figure 3. Selected HMBC ( $)$ and $\operatorname{COSY}(\square)$ correlations of planifoliusin A (9). 


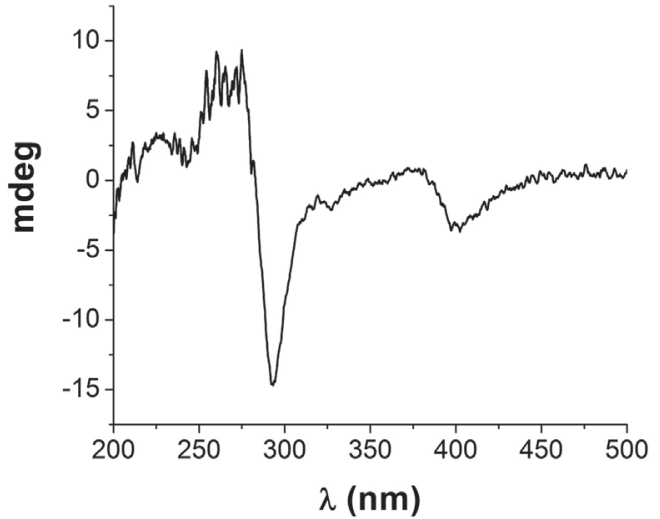

Figure 4. CD spectrum (solvent: acetonitrile) of planifoliusin A (9) isolated from P. planifolius capitula.

Vioxanthin (7) was identified by comparison of its ${ }^{1} \mathrm{H}$ NMR, ${ }^{13} \mathrm{C}$ NMR and MS data with literature values. ${ }^{18}$ Additionally, the CD spectrum of vioxanthin (7) allowed to confirm the $(P, R, R)$-vioxanthin. ${ }^{23}$

\section{Antimicrobial activities of isolated compounds}

Planifoliusin A (9) and vioxanthin (7) showed the respective MIC values of 1000 and $500 \mu \mathrm{g} \mathrm{mL}^{-1}$ for E. coli; 500 and $1000 \mu \mathrm{g} \mathrm{mL}^{-1}$ for S. setubal; both compounds exhibited significant activity against $S$. aureus with MIC values of 15.6 (9) and $7.8 \mu \mathrm{g} \mathrm{mL}^{-1}$ (7); and MIC values above $1000 \mu \mathrm{g} \mathrm{mL} \mathrm{m}^{-1}$ for C. albicans (Table 1). It has been commonly described that plant extracts are more active against Gram-positive bacteria than against Gram-negative bacteria. ${ }^{24}$ The existing difference between them can be explained because the cell walls of Gram-negative bacteria are less permeable to antimicrobial metabolites..$^{25}$ In addition, the results for the $\mathrm{MBC}$ showed that the EtOAc extract and the compounds $\mathbf{9}$ and $\mathbf{7}$ displayed bactericidal activity from 62.5 to $1000 \mu \mathrm{g} \mathrm{mL}^{-1}$, while for $S$. aureus these compounds showed MBC of 62.5 (9) and $250 \mu \mathrm{g} \mathrm{mL}^{-1}$ (7), indicating bacteriostatic behavior of these compounds for $S$. aureus.

The compounds $\mathbf{9}$ and $\mathbf{7}$ displayed a good antibacterial activity for the strains tested and, together with the results of the EtOAc extract, have shown pronounced efficacy against the Gram-positive bacteria $S$. aureus.

\section{Conclusions}

The LC-ESI-MS ${ }^{\mathrm{n}}$ analysis established a method for identifying naphthopyranones in the EtOAc extract of capitula from Paepalanthus planifolius in which 15 compounds were characterized. This is the first report on naphthopyranones dimers in Paepalanthus by LC-MS and this methodology could be used to identify these naphthopyranones in other Paepalanthus species.
It is also suggested that the antimicrobial activity against Staphylococcus aureus shown by the EtOAc extract is due to the presence of naphthopyranones derivatives, including the new planifoliusin A (9) compound and vioxanthin (7). Future studies may be made to isolate the new naphthopyranones dimers proposed (10-15) to obtain spectroscopic data and their antimicrobial activities.

\section{Experimental}

\section{General experimental procedures}

${ }^{1} \mathrm{H}$ NMR (600 MHz), ${ }^{13} \mathrm{C}$ NMR (150 MHz), gHMBC, gHSQC and gCOSY experiments were conducted on a Bruker Avance III 600 spectrometer using the nondeuterated residual solvent signal as a reference. Optical rotation was measured on a PerkinElmer 341-LC polarimeter. Circular dichroism was measured on a Jasco J-815 CD spectrometer. HPLC separations were carried out on a Jasco (PU-2089 Solvent Delivery Module and AS-2055 AutoSampler) coupled with a Jasco MD-2018 photodiode array detector (DAD) system using an RP-18 column (Knauer, Eurospher II $250.0 \times 8.0 \mathrm{~mm}, 5 \mu \mathrm{m}$, flow rate $3.2 \mathrm{~mL} \mathrm{~min}^{-1}$ ) along with the protective guard column Phenomenex $(4 \times 3 \mathrm{~mm})$. All solvents were purchased from Sigma-Aldrich (St. Louis, MO, USA), and Tedia (Fairfield, $\mathrm{OH}, \mathrm{USA}$ ) for HPLC analysis. The chromatography column was carried out on Sephadex LH-20 $(75 \times 2.0 \mathrm{~cm}$, i.d. $)$ obtained from Merck (Darmstadt, Germany).

\section{LC-MS analysis}

For the LC-MS analysis, $2.0 \mathrm{mg}$ of the extract was dissolved in $2 \mathrm{~mL}$ of methanol:water $(7: 3, \mathrm{v} / \mathrm{v})$. For both the analyses, the solution was filtered through a $0.22 \mu \mathrm{m}$ polytetrafluoroethylene (PTFE) membrane and aliquots of $10 \mu \mathrm{L}$ were directly injected into the LC-MS system.

The LC-ESI-TOF-HRMS experiment was performed using a UFLC (Shimadzu, Japan) containing two LC20AD solvent pumps, a SIL20A $\mathrm{A}_{\mathrm{HT}}$ auto sampler, a CTO20A column oven and a CBM20A system controller and a diode array detector (SPD-M20AV), coupled with a microTOF (Bruker Daltonics, USA) mass spectrometer. The analyses were performed under the following conditions: capillary voltage, $3.5 \mathrm{kV}$; capillary temperature, $220{ }^{\circ} \mathrm{C}$; end plate offset voltage, $490 \mathrm{~V}$; nebulizer gas pressure, 5.5 bar; dry gas $\left(\mathrm{N}_{2}\right), 10 \mathrm{~L} \mathrm{~min}^{-1}$. Mass spectra were measured from $\mathrm{m} / \mathrm{z}$ 50-1300 in positive ion mode.

The LC-ESI-IT-MS/MS analyses were performed using a UFLC (Shimadzu), coupled with an AmaZon SL ion trap mass spectrometer (Bruker). The ion trap acquisition 
parameters were as follows: capillary voltage, $3.5 \mathrm{kV}$; end plate offset, $500 \mathrm{~V}$; nebulizer gas pressure, $60 \mathrm{psi}$; dry gas $\left(\mathrm{N}_{2}\right), 10 \mathrm{~L} \mathrm{~min}^{-1}$; dry gas temperature, $320{ }^{\circ} \mathrm{C}$. CID fragmentation was achieved in auto-MS/MS mode.

The analysis was performed using a gradient mode, eluted with a water:methanol gradient (70-92\% methanol, $45 \mathrm{~min}$ ) containing $0.1 \%$ formic acid, the flow rate was $1.0 \mathrm{~mL} \mathrm{~min}{ }^{-1}$, RP-18 column (Knauer, Eurospher II $250.0 \times 4.6 \mathrm{~mm}, 5 \mu \mathrm{m})$ along with the protective guard column (Phenomenex, $4 \times 3 \mathrm{~mm}$ ) and the column oven was set at $30{ }^{\circ} \mathrm{C}$. The software Bruker Compass DataAnalysis 4.2 was used to control the system, for data collection, and processing. The mass analyzer was calibrated using a solution of sodium trifluoroacetic acid as the internal standard.

\section{Plant material}

Authenticated Paepalanthus planifolius (Bong.) Körn (Eriocaulaceae) was collected in the Serra do Cipó, Minas Gerais, Brazil, 19¹3'21.64'S, 43³0'04.06”'W, in October of 2013 and identified by Prof Dr Paulo Takeo Sano. A voucher specimen (Sano 4979) was deposited at the Institute of Biosciences, USP, São Paulo, Brazil.

\section{Extraction and isolation}

The dried powder of the P.planifolius capitula (50.1 g) was extracted with ethyl acetate (EtOAc, $1 \mathrm{~L}$ ) for $48 \mathrm{~h}$ at room temperature by maceration and the same process was repeated for five times until exhaustion of the plant material. The solution was evaporated to dryness in vacuo to give the EtOAc extract $\left(1.7 \mathrm{~g}, 3.4 \%\right.$ ), which was stored at $4{ }^{\circ} \mathrm{C}$.

A portion of the extract $(200 \mathrm{mg}$ ) was solubilized in EtOAc $(5.0 \mathrm{~mL})$ using ultrasound for $10 \mathrm{~min}$ and then centrifuged for $15 \mathrm{~min}$. The precipitate $(14 \mathrm{mg})$ was separated from the supernatant. The supernatant was filtered and fractionated by gel permeation chromatography using a Sephadex LH-20 column and eluted with EtOAc to give 5 fractions which were analyzed by silica gel thin layer chromatography (TLC, chloroform:EtOAc, 1:1, v/v, organic phase). Fractions 3-5 were combined and further purified by semipreparative HPLC-DAD which led to the isolation of planifoliusin $\mathrm{A}(\mathbf{9}, 2.5 \mathrm{mg})$ and vioxanthin $(\mathbf{7}, 11.2 \mathrm{mg})$.

\section{Antimicrobial activities}

Antibacterial activity and minimum bactericidal concentration (MBC)

The evaluation of the antibacterial activity and the minimal inhibitory concentration (MIC) were determined by the broth microdilution method, as described in the M7-A6 reference guideline of the Clinical and Laboratory Standards Institute. ${ }^{26}$ The biological activity was evaluated against the bacteria $E$. coli (ATCC 25922), S. setubal (ATCC 19196) and S. aureus (ATCC 25923), all the microorganisms were obtained from the American Type Culture Collection (Rockville, MD, USA). They are incubated in the Muller-Hinton broth for $24 \mathrm{~h}$ at $37^{\circ} \mathrm{C}$. These inoculums were standardized at $1.0 \times 10^{8} \mathrm{CFU} \mathrm{mL}^{-1}$ (corresponding to $0.5 \mathrm{McFarland}$ standards) by adjusting the optical density to $0.10-0.15$ at $620 \mathrm{~nm}$. The assay was carried out in 96-well microplates containing $80 \mu \mathrm{L}$ of Muller-Hinton broth and $20 \mu \mathrm{L}$ of standardized inoculum.

The extract and the substances 9 and 7 were dissolved in DMSO: $\mathrm{H}_{2} \mathrm{O}(2: 8, \mathrm{v} / \mathrm{v})$ to initial concentrations of $1000 \mu \mathrm{g} \mathrm{mL} \mathrm{m}^{-1}$. A two-fold serial dilution was carried out in order to obtain concentration ranging from 7.81 to $1000 \mu \mathrm{g} \mathrm{mL}^{-1}$ and $100 \mu \mathrm{L}$ of each concentration were added to 96-well microplates. Ampicillin was used as positive control while DMSO: $\mathrm{H}_{2} \mathrm{O}(2: 8, \mathrm{v} / \mathrm{v})$ was used as the negative control. The plates were incubated at $37{ }^{\circ} \mathrm{C}$ for $24 \mathrm{~h}$. The assay was displayed in triplicate.

The MIC of the samples was detected using spectrophotometric reading at $595 \mathrm{~nm}$ and with the addition of $30 \mu \mathrm{L}$ of resazurin solution $\left(100 \mu \mathrm{g} \mathrm{mL} \mathrm{m}^{-1}\right)$, incubated at $37^{\circ} \mathrm{C}$ for $2 \mathrm{~h}$. The growth of bacteria changes the blue dye resazurin into a pink. The color pink indicates positive growth, whereas the color blue indicates growth inhibition. MIC was defined as the lowest sample concentration which prevented this change and exhibited inhibition of microorganism growth. For the determination of minimal bactericidal concentration (MBC), a portion from each well that showed antibacterial activity was plated on Muller-Hinton agar and incubated at $37^{\circ} \mathrm{C}$ for $24 \mathrm{~h}$. The lowest concentration that showed no bacteria growth in the subcultures was used as the MBC. ${ }^{6}$

Antifungal activity and minimum fungicidal concentration (MFC)

The evaluation of the antifungal activity and the minimal inhibitory concentration (MIC) were determined by the broth microdilution method, as described in the M27-A3 reference guideline of the Clinical and Laboratory Standards Institute, with modifications. ${ }^{27,28}$ The biological activity was evaluated against the fluconazole-resistant Candida albicans (ATCC 10231).

The yeast strain was incubated in $100 \mu \mathrm{L}$ of RPMI 1640 (adjusted to $\mathrm{pH} 7.0$ with 3-( $\mathrm{N}$-morpholino) propanesulfonic acid (MOPS) buffer, $0.165 \mathrm{~mol} \mathrm{~L}^{-1}$ ) for $48 \mathrm{~h}$ at $37^{\circ} \mathrm{C}$. The inoculum of yeast was standardized at $5.0 \times 10^{6} \mathrm{CFU} \mathrm{mL}^{-1}$ (corresponding to $0.5 \mathrm{McFarland}$ standards) by adjusting 
the optical density to $0.12-0.15$ at $530 \mathrm{~nm}$. The assay was carried out in 96-well microplates containing $100 \mu \mathrm{L}$ of RPMI 1640 followed by a two-fold serial dilution to obtain concentration ranges of $7.81-1000 \mu \mathrm{g} \mathrm{mL}^{-1}$ to the extract and the isolated compounds. Fluconazole and amphotericin B were used as a positive control while DMSO: $\mathrm{H}_{2} \mathrm{O}(2: 8, \mathrm{v} / \mathrm{v})$ was used as the negative control. The plates were incubated at $37^{\circ} \mathrm{C}$ for $48 \mathrm{~h}$. The assay was displayed in triplicate.

The MIC of the samples was detected using spectrophotometric reading at $595 \mathrm{~nm}$ after the addition of $20 \mu \mathrm{L}$ triphenyl-tetrazolium chloride (TTC) solution $\left(0.02 \mathrm{~g} \mathrm{~mL}^{-1}\right)$ incubated at $37{ }^{\circ} \mathrm{C}$ for $2 \mathrm{~h}$. Yeast growth changes the colorless TTC to red. MIC was defined as the lowest sample concentration that prevented this change and exhibited inhibition of microorganism growth. For the determination of minimal fungicidal concentration (MFC), a portion from each well that showed antibacterial activity was plated on Sabouroud agar and incubated at $37{ }^{\circ} \mathrm{C}$ for $48 \mathrm{~h}$. The lowest concentration that demonstrated no yeast growth in the subcultures was used as the MFC. ${ }^{6}$

\section{Supplementary Information}

Supplementary information $\left({ }^{1} \mathrm{H}\right.$ and ${ }^{13} \mathrm{C}$ spectra for compounds 7 and $\mathbf{9}, \mathrm{CD}$ spectrum of vioxanthin (7), UV spectra and LC-MS analyses for compounds 1-15 and proposed fragmentation pathways of compounds 7-15) is available free of charge at http://jbcs.sbq.org.br as a PDF file.

\section{Acknowledgments}

We would like to thank the Coordenação de Aperfeiçoamento de Pessoal de nível Superior (CAPES) for the scholarships awarded to M. R. A. We also thank the Fundação de Amparo à Pesquisa do Estado de São Paulo (FAPESP) which provided a fellowship for F. H. (grant No. 2013/12564-6) and a project for L. C. S. (grant No. 2015/04899-3) and T. M. B. (grant No. 2013/25432-0). We would also like to thank Conselho Nacional de Pesquisa (CNPq) for the scholarships awarded to the L. C. S. The authors would like to thank the Prof Dr Marcelo Trovó Lopes de Oliveira for providing the photo of the Paepalanthus planifolius.

\section{References}

1. Plata, K.; Rosato, A. E.; Wegrzyn, G.; Acta Biochim. 2009, 56, 597.

2. Cragg, G. M.; Newman, D. J.; Biochim. Biophys. Acta 2013, 1830, 3670.
3. Giulietti, A. M.; Hensold, N.; Parra, L. R.; Andrade, M. J. G.; Van Den Berg, C.; Harley, R. M.; Phytotaxa 2012, 60, 50.

4. Forzza, R. C.; Baumgratz, J. F. A.; Bicudo, C. E.; Carvalho Jr., A. A.; Costa, A.; Costa, D. P.; Hopkins, M.; Leitman, P. M.; Lohmann, L. G.; Maia, L. C.; Martinelli, G.; Menezes, M.; Morim, M. P.; Coelho, M. A. N.; Peixoto, A. L.; Pirani, J. R.; Prado, J.; Queiroz, L. P.; Souza, V. C.; Stehmann, J. R.; Sylvestre, L. S.; Walter, B. M. T.; Zappi, D.; Catálogo de Plantas e Fungos do Brasil, vol. 1.; Andrea Jakobsson Estúdio: Rio de Janeiro, 2010, p. 86.

5. Giulietti, A. M.; Pirani, J. R.; Harley, R. M. In Centres of Plant Diversity: A Guide and Strategies for the Conservation, vol. 3.; Davis, S. D.; Heywood, V. H.; Herrera-MacBryde, O.; Villa-Lobos, J.; Hamilton, A. C., eds.; WWF-IUCN: Cambridge, 1997, p. 397.

6. Araújo, M. G. F.; Hilário, F.; Nogueira, L. G.; Vilegas, W.; Santos, L. C.; Bauab, T. M.; Molecules 2011, 16, 10479.

7. Araújo, M. G. F.; Pacífico, M.; Vilegas, W.; Santos, L. C.; Icely, P. A.; Miró, M. S.; Scarpa, M. V. C.; Bauab, T. M.; Sotomayor, C. E.; Med. Mycol. 2013, 51, 673.

8. Amaral, F. P.; Napolitano, A.; Masullo, M.; Santos, L. C.; Festa, M.; Vilegas, W.; Pizza, C.; Piacente, S.; J. Nat. Prod. 2012, 75, 547.

9. Amorim, M. R.; Rinaldo, D.; Amaral, F. P.; Vilegas, W.; Magenta, M. A. G.; Vieira Jr., G. M.; Santos, L. C.; Quim. Nova 2014, 37, 1122.

10. Santos, L. C.; Piacente, S.; Pizza, C.; Albert, K.; Dachtler, M.; Vilegas, W.; J. Nat. Prod. 2001, 64, 122.

11. Kitagawa, R. R.; Raddi, M. S. G.; Santos, L. C.; Vilegas, W.; Chem. Pharm. Bull. 2004, 52, 1487.

12. Coelho, R. G.; Batista, L. M.; Santos, L. C.; Rev. Bras. Cienc. Farm. 2006, 42, 413.

13. Fang, J.-J.; Ye, G.; Chen, W.-L.; Zhao, W.-M.; Phytochemistry 2008, 69, 1279.

14. Ramos, M. A. S.; Toledo, L. G.; Calixto, G. M. F.; Bonifácio, B. V.; Araújo, M. G. F.; Santos, L. C.; Almeida, M. T. G.; Chorilli, M.; Bauab, T. M.; Int. J. Mol. Sci. 2016, 17, 1368.

15. Holetz, F. B.; Pessini, G. L.; Sanches, N. R.; Cortez, D. A.; Mem. Inst. Oswaldo Cruz 2002, 97, 1027.

16. Vilegas, W.; Dokkedal, A. L.; Rastrelli, L.; Piacente, S.; Pizza, C.; J. Nat. Prod. 1999, 62, 746.

17. Vilegas, W.; Santos, L. C.; Alécio, A. C.; Pizza, C.; Piacente, S.; Pauw, E. D.; Sano, P. T.; Phytochemistry 1998, 38, 207.

18. Alvarado, J. G.; Abad-Reyes, J. A.; Montealegre, R.; AmaroLuis, J. M.; Av. Quim. 2013, 8, 131.

19. Vilegas, W.; Roque, N. F.; Salatino, A.; Giesbrecht, A. M.; Davino, S.; Phytochemistry 1990, 29, 2299.

20. Coelho, R. G.; Vilegas, W.; Devianne, K. F.; Raddi, M. S. G.; Fitoterapia 2000, 71, 497.

21. Saeed, A.; Eur. J. Med. Chem. 2016, 116, 290.

22. Drochner, D.; Muller, M.; Eur. J. Org. Chem. 2001, 211. 
23. Bode, S. E.; Drochner, D.; Muller, M.; Angew. Chem., Int. Ed. 2007, 46, 5916

24. Vlietinck, A. J.; Van Hoof, L.; Totté, J.; Lasure, A.; Vanden Berghe, D.; Rwangabo, P. C.; Mvukiyumwami, J.; J. Ethnopharmacol. 1995, 46, 31.

25. Adamu, M.; Naidoo, V.; Eloff, J. N.; BMC Vet. Res. 2014, $10,1$.

26. Clinical and Laboratory Standards Institute (CLSI); Methods for Dilution Antimicrobial Susceptibility Tests for Bacteria that Grow Aerobically, $6^{\text {th }}$ ed.; Document M7-A6; Clinical and Laboratory Standards Institute (CLSI): Wayne, Pennsylvania, USA, 2006
27. Clinical and Laboratory Standards Institute (CLSI); Reference Methods for Broth Dilution Antifungal Susceptibility Tests for Yeasts; Document M27-A3; Clinical and Laboratory Standards Institute (CLSI): Wayne, Pennsylvania, USA, 2008.

28. Duarte, M. C. T.; Figueira, G. M.; Sartoratto, A.; Rehder, V. L. G.; Delarmelina, C.; J. Ethnopharmacol. 2005, 97, 305.

Submitted: May 8, 2017 Published online: November 10, 2017 